\title{
KURBAN HEWAN DALAM UPACARA YADNYA: MEMBUNUH ATAU MEMULIAKAN?
}

\author{
Ni Nyoman Oktaria Asmarani
}

Environmental Educator di R.O.L.E Foundation

Email: oasmarani@gmail.com

\section{Abstrak}

Salah satu ibadah yang dilakukan masyarakat Hindu Bali bisa dilihat dari upacara Yadnya. Yadnya sendiri berarti kurban suci yang dilakukan secara tulus ikhlas untuk dipersembahkan kepada Tuhan, yakni Ida Sang Hyang Widhi Wasa. Dalam prosesnya, umat Hindu Bali biasa menggunakan hewan sebagai sesuatu yang dikurbankan untuk upacara Yadnya. Bagi para pegiat animal welfare, penggunaan hewan ini dianggap sebagai sesuatu yang tidak patut karena itu berarti hewan hanya dimaknai sebatas pemenuh keperluan manusia saja. Padahal, hewan memiliki hak untuk hidup, sama layaknya manusia. Walaupun begitu, sebenarnya ada banyak dimensi yang bisa ditilik dari penggunaan hewan dalam upacara Yadnya ini. Artikel ini meninjau secara kritis budaya penggunaan hewan sebagai kurban Yadnya dan juga bagaimana animal welfare memandang budaya tersebut. Tujuan ini akan dijabarkan melalui jawaban atas pertanyaan-pertanyaan: Apa yang melatarbelakangi masyarakat Hindu Bali menggunakan hewan dalam upacara Yadnya?; Bagaimana hewan digunakan dalam upacara Yadnya? dan; Bagaimana pengorbanan hewan dalam berbagai upacara dilihat dengan perspektif animal welfare? Hasil dari penelitian kepustakaan ini memperlihatkan bahwa penggunaan hewan sebagai kurban dalam upacara Yadnya di agama Hindu ternyata memiliki latar belakang yang kompleks. Perlakuan ini tidak bisa semata-mata disebut sebagai pembunuhan hewan karena ia mengandung nilai-nilai yang juga dipercaya dapat memuliakan hewan itu sendiri.

Kata kunci: Yadnya, Hindu, pengorbanan hewan, kesejahteraan hewan, hak hewan 


\section{Abstract}

One of the worships performed by the Balinese Hindu community can be seen from the Yadnya ceremony. Yadnya itself means a sacrifice made sincerely to be offered to God, namely Ida Sang Hyang Widhi Wasa. In the process, Balinese Hindus used to use animals as sacrifices for the Yadnya ceremony. For animal welfare activists, the use of these animals is considered as something inappropriate because it means that animals are only meant to fulfill human needs. In fact, animals have the right to live, just like humans. Even so, there are actually many dimensions that can be seen from the use of animals in this Yadnya ceremony. This article will critically examine the culture of sacrificing animals in Yadnya and how animal welfare sees that culture. This objective will be elaborated through the answers to the questions: What is the rationale of Balinese Hindu community in using animals for Yadnya ceremony?; How are animals used in the Yadnya ceremony? and; How is animal sacrifice in various ceremonies seen by the perspective of animal welfare? The result of this bibliographical research shows that the use of animals as sacrifices in the Yadnya ceremony in Hinduism turned out to have a complex background. This treatment cannot simply be called killing animals because they contain values that are also believed to be able to respect the animal itself.

Keywords: Yadnya, Hindu, animal sacrfice, animal welfare, animal rights

\section{PENDAHULUAN}

Salah satu bentuk ibadah yang dilakukan umat Hindu Bali adalah melalui Yajna atau sering ditulis Yadnya. Kata Yadnya berasal dari kata Yaj (bahasa Sansekerta) yang berarti kurban, pemujaan. Yadnya berarti upacara kurban suci (Tim Penyusun, 1996). Pengorbanan ini dilakukan oleh manusia sebagai tanda rasa terima kasih dan rasa cintanya terhadap Tuhan. Manusia berterima kasih sebab ia merasa diselamatkan atau dikabulkan permohonannya. Akibat kemurahan hati dari Tuhan, muncullah rasa cinta manusia kepada-Nya (Pidarta, 2016). Selain itu, tujuan lain dari pelaksanaan Yadnya adalah sebagai pengejawantahan 
ajaran Weda, peningkatan kualitas diri, penghubung antara diri dan yang dipuja, dan juga penyucian terhadap diri.

Tujuan-tujuan tersebut hendak dicapai melalui berbagai sarana yang disebut upakara atau banten (sesajen). Secara etimologis, upakara berarti "pelayanan yang ramah tamah atau kebaikan hati". Maka dari itu, setiap upakara yang dipersembahkan harus berdasar pada ketulusan, kemantapan, dan kesucian hati (Tim Penyusun, 1996). Walaupun begitu, karena setiap orang ingin menyalurkan rasa terima kasih dan cinta dengan sepenuh hati, maka terdapat berbagai variasi sesajen, baik dalam isi maupun bentuknya. Hal ini kemudian membuat suatu tata pelaksanaan Yadnya, yaitu upacara. Kata upacara, dalam bahasa Sanskerta, berarti "mendekati". Maka dari itu, dalam setiap upacara diharapkan terjadinya suatu upaya untuk mendekatkan diri kepada Sang Hyang Widhi Wasa, kepada sesama manusia, kepada alam lingkungan, kepada leluhur, dan kepada para Rsi.

Umat Hindu Bali sering kali menggunakan hewan sebagai bagian dari upakara. Hewan yang digunakan pun beragam, tetapi yang lazim adalah sapi, babi, anjing, ayam, bebek. Penggunaan hewan dalam upakara Yadnya ini sudah dilakukan sejak turun temurun, dan bahkan tercantum dalam kitab-kitab keagamaan Hindu. Maka dari itu, kegiatan ini dapat disebut sebagai budaya karena merupakan hasil cipta, rasa, dan karsa manusia. Kegiatan ini juga terus menerus diadakan secara turun temurun sehingga keberadaannya tetap terjaga hingga kini.

Selagi umat Hindu terus melaksanakan praktik penggunaan hewan dalam upacara-upacara Yadnya, terdapat sebuah kesadaran baru untuk memperhatikan kesejahteraan hewan. Pembahasan terkait kesejahteraan hewan (animal welfare) secara filosofis diperkenalkan oleh Peter Singer dalam bukunya, Animal Liberation. Animal Liberation membahas pentingnya manusia untuk memperhatikan bahwa hewan memiliki hak. Hewan yang sekian lama hanya dianggap sebagai makhluk yang tingkatannya berada 
di bawah manusia layak disebut memiliki hak karena ia memiliki kemampuan untuk merasa (sentience) dan karenanya, mampu merasakan sakit (suffer) (Singer, 2002).

Hal inilah yang kemudian menggerakkan kesadaran banyak orang dan memulai gerakan untuk melindungi dan menjunjung kesejahteraan dan hak-hak hewan. Berbagai kegiatan manusia yang dirasa merugikan dan menyakiti hewan mulai ditentang oleh berbagai orang. Pembunuhan hewan pun juga merupakan salah satu kegiatan yang ditentang oleh para pegiat hak-hak hewan. Maka dari itu, budaya yang telah terbiasa menggunakan hewan sebagai kurban (yang mana itu diartikan bahwa manusia malah mengabaikan hak-hak hewan), mulai dicoba untuk ditinggalkan perlahan-lahan dengan sebuah budaya baru, yakni budaya untuk menghargai hak-hak hewan. Oleh karenanya, dapat disebut bahwa terjadi adanya pergeseran budaya dalam memandang relasi hewan dan manusia. Pergeseran ini dapat menimbulkan kritik-kritik baru, baik terhadap budaya yang tergeser, budaya yang menggeser, atau pergeseran itu sendiri.

Kritik budaya adalah salah satu hal yang lazim dilakukan dalam kajian budaya. Kritik adalah kecaman atau tanggapan, atau kupasan yang kadang-kadang disertai uraian dan pertimbangan baik buruk terhadap suatu hasil karya, pendapat, dan sebagainya. Oleh karena itu, kritik budaya berarti mengupas suatu kebudayaan untuk melihat dan menganalisisnya lebih jelas dan dalam, sekaligus memilah mana yang dianggap baik dan buruk. Bagi Kleden (Kleden, 1987), kritik budaya justru dianggap perlu untuk dilakukan sebab kebudayaan adalah suatu entitas yang diciptakan oleh manusia. Maka dari itu, ia seharusnya bersifat tidak ajeg dan lazim untuk bersifat dinamis. Kebudayaan adalah sesuatu yang seyogianya terbuka atas kritik sebab ia memang berkembang sesuai zaman dan kebutuhan hidup manusia dan sekelilingnya. 
Oleh karena itu, artikel ini akan meninjau secara kritis budaya penggunaan hewan sebagai kurban Yadnya dan juga bagaimana animal welfare memandang budaya tersebut. Tujuan ini akan dijabarkan melalui jawaban atas pertanyaan-pertanyaan: Apa yang melatarbelakangi masyarakat Hindu Bali menggunakan hewan dalam upacara Yadnya?; Bagaimana hewan digunakan dalam upacara Yadnya? dan; Bagaimana pengorbanan hewan dalam berbagai upacara dilihat dengan perspektif animal welfare?

\section{YADNYA DAN PENGGUNAAN HEWAN DI DALAMNYA}

Yadnya memiliki beberapa tujuan, salah satunya adalah sebagai pengejawantahan ajaran Weda, kitab suci sekaligus dasar agama Hindu. Tertulis pada Rg Veda X.71.11, umat Hindu memiliki empat cara utama untuk mengungkapkan ajaran Weda:

"Rcam tvah posagaste pupusvan

Gayatram tvo gayati savavarisu

Brahma tvo vadati jatavidyam

Yajnasya matram vi mimita u tvah"

Dikutip dari Tim Penyusun (1996), arti dari sloka ini adalah, "Seorang bertugas mengucapkan sloka-sloka Weda, seorang melakukan nyanyian-nyanyian pujian dalam Sakwari; seorang lagi yang menguasai pengetahuan Weda, mengajarkan isi Weda; dan yang lain mengajarkan tata cara melaksanakan kurban suci (Yadnya)." Sloka ini menegaskan bahwa Yadnya merupakan pengejawantahan ajaran Weda yang dilukiskan dalam bentuk simbol-simbol (niyasa). Niyasa ini tercermin dalam upakara yang menyertai Yadnya. Melalui niyasa dalam Yadnya itu, realisasi ajaran-ajaran agama terwujud sebagai sesuatu yang lebih mudah dihayati dan dilaksanakan oleh umat kebanyakan. Selain itu, umat Hindu juga sekaligus dapat meningkatkan kemantapan dalam pelaksanaan kegiatan keagamaan itu sendiri. Adanya niyasa yang terdapat dalam Yadnya mengizinkan umat Hindu yang ingin 
menghadirkan Tuhan yang akan disembah dengan lebih dekat, sekaligus mempersembahkan isi dunia yang paling baik.

Tujuan lain dari Yadnya adalah sebagai ungkapan rasa terima kasih. Bhagawadgita menjelaskan bahwa Tuhan menciptakan manusia melalui Yadnya, dan dengan Yadnya pula, manusia akan mencapai kebaikannya yang maha tinggi. Dalam Bhagawadgita III.11, disebutkan bahwa:

\section{"Devān bhāvayatā 'nena \\ Te devā bhā̄vayantu vah \\ Parasparam bhāvayantah \\ Sreyah param avāpsyastha"}

Arti dari sloka ini adalah, dikutip dari Tim Penyusun (1996), “Dengan ini kamu memelihara para dewa dan dengan ini pula para dewa memelihara dirimu, jadi dengan saling memelihara satu sama lain, kamu akan mencapai kebaikan yang maha tinggi." Oleh karena itu, terjadi hubungan timbal balik antara pencipta dan makhluk yang diciptakannya. Ketika Tuhan menciptakan manusia dengan Yadnya, maka sebaliknya, manusia pun memelihara para dewata dengan cara mempersembahkan Yadnya. Hal ini adalah bentuk terima kasih manusia kepada Tuhan karena Ia telah menciptakan alam semesta beserta isinya dan mampu membuat manusia hidup bersama-sama dengan berbagai makhluk hidup lainnya.

Rasa terima kasih manusia dikarenakan adanya timbal balik sekaligus ketergantungan ini. Ketergantungan ini berjumlah tiga dan ketiganya menyebabkan utang yang disebut sebagai Tri Rna (tiga utang). Ketergantungan terhadap Tuhan sebagai pencipta sekaligus pemelihara disebut Dewa Rna. Ketergantungan kepada leluhur yang telah mengasuh dan menghidupi disebut Pitra Rna. Ketergantungan terhadap para rsi dan guru yang membebaskan hidup dari kebodohan menuju kebahagiaan hidup disebut sebagai Rsi Rna. Rasa terima kasih manusia atas pengorbanan suci/Yadnya 


\section{2}

yang telah diterima dalam kehidupannya, "dibalas" kembali oleh manusia dengan Yadnya itu sendiri. Maka dari itu, Yadnya bisa disebut sebagai ungkapan terima kasih (Tim Penyusun, 1996).

Tujuan selanjutnya dari Yadnya adalah untuk meningkatkan kualitas diri. Pada dasarnya, Yadnya merupakan pengorbanan suci yang dimaksudkan untuk mengurangi rasa keakuan (ego) sekaligus pencarian kenikmatan hidup yang lebih tinggi. Setiap pengorbanan suci memberi jalan bagi pertumbuhan jiwa. Selain itu, Yadnya juga bertujuan untuk mengurangi rasa keakuan (ego). Setiap pengorbanan suci yang dilakukan manusia, dapat memberi jalan bagi pertumbuhan jiwa. Pengorbanan, pada dasarnya, adalah keikhlasan berbuat untuk tujuan yang lebih mulia. Maka dari itu, dengan melakukan Yadnya, manusia sekaligus belajar untuk mengikhlaskan sesuatu untuk mementingkan sesuatu yang lebih utama, yaitu Tuhan. Melalui Yadnya pula, tersirat adanya pengakuan atas keterbatasan, kekurangan, dan kepapaan hidup kita sebagai ciptaan Tuhan (Tim Penyusun, 1996).

Tujuan paling utama dari pelaksanaan Yadnya, selain sebagai persembahan terhadap Tuhan dan juga sebagai sarana menghubungkan diri kepada-Nya, adalah untuk membersihkan dan menyucikan baik diri, lingkungan, dan alam semesta. Kesucian adalah sesuatu yang ditegakkan dalam agama Hindu sebab ia dapat melahirkan kualitas spiritual yang lebih tinggi kepada manusia. Selain itu, penyucian juga menjadi salah satu bentuk rasa cinta kita terhadap Tuhan sebagai pencipta (Tim Penyusun, 1996).

Yadnya dengan segala tujuannya diwujudkan melalui lima bentuk besar yang biasa disebut sebagai Panca Yadnya. Lima bentuk Yadnya ini merupakan pengejawantahan dari Tri Rna. Bentuk pertama adalah Dewa Yadnya, yakni pengorbanan kepada Ida Sang Hyang Widhi Wasa atas segala anugerah yang telah dilimpahkan. Bentuk yang kedua adalah Rsi Yadnya yang 
merupakan ungkapan terima kasih terhadap Rsi dan mahaguru yang telah menuntun kehidupan manusia. Bentuk ketiga adalah Pitra Yadnya, yakni pengorbanan yang dilakukan kepada leluhur yang telah memelihara manusia. Bentuk keempat, Manusa Yadnya, adalah pengorbanan yang dilakukan kepada sesama manusia untuk mencapai keselamatan lahir batin di dunia dan akhirat. Sedangkan bentuk terakhir adalah Bhuta Yadnya, yakni pengorbanan terhadap manifestasi Tuhan dalam bentuk hewan, tumbuhan, dan makhluk-makhluk lainnya yang telah menunjang kehidupan di alam semesta (Pidarta, 2016).

Bhagawadgita menyebutkan bahwa Yadnya kemudian dikelompokkan kembali atas dasar sarana yang dipersembahkan serta cara pelaksanaannya. Pengelompokan ini menghasilkan empat jenis Yadnya. Tapa Yadnya yakni pengorbanan dengan cara mengendalikan indria (penggerak keinginan); Drwya Yadnya yaitu pengorbanan materi atau harta benda milik manusia; Jnana Yadnya yakni mengamalkan pengetahuan dan kebijaksanaan untuk kesejahteraan dan kebahagiaan kehidupan di dunia; dan Yoga Yadnya yaitu melaksanakan yoga (pengaturan nafas dan pemusatan pikiran) untuk menghubungkan diri dengan-Nya. Penggolongan Yadnya ini menunjukkan bahwa pengorbanan yang dilakukan umat Hindu tidaklah mesti berupa materi. Ia dapat berupa hal lain yang memang bertujuan sama, yaitu pengorbanan suci secara tulus ikhlas (Tim Penyusun, 1996).

Yadnya pun dikelompokkan kembali menjadi tiga tingkatan ketika dilihat dari upakara yang digunakan. Tingkatan-tingkatan ini adalah Kanista (kecil), Madya (sedang), dan Utama (besar). Perbedaan tingkatan ini disesuaikan dengan tingkat kemampuan umat yang akan melaksanakan Yadnya. Dengan begitu, pelaksanaan Yadnya justru akan membawa kebahagiaan dan kesucian batin, bukan membawa derita bagi pelaksananya. Walaupun begitu, dari segi kualitas, tingkatan Yadnya itu tidak memiliki perbedaan apapun selama pelaksanaannya didasari 
dengan rasa bhakti, ketulusan, dan kesucian hati (Tim Penyusun, 1996).

Umat Hindu seringkali menggunakan hewan sebagai bagian dari upakara. Penggunaan hewan sebagai unsur upakara dalam Yadnya tentunya tidaklah tanpa sebab. Penggunaan hewan sudah disebutkan dalam berbagai kitab yang menjadi acuan umat Hindu dalam melaksanakan agamanya. Diketahui dari kitab Manawa Dharmasastra V.42, dicantumkan bahwa Tuhan menciptakan binatang dan tumbuhan untuk tujuan upacaraupacara kurban, dengan maksud untuk kebaikan bumi:

"Eesvarthesu pacunhimsan veda,

tattvarthavid dvijah,

atmanam ca pacum caiva ga, mayatyutanam gatim"

Arti dari sloka ini adalah, dikutip dari Pudja dan Sudantra (Pudja, I G., \& Sudantra, 1973), “Seorang yang mengetahui arti sebenarnya dari Weda, menyembelih seekor hewan dengan tujuan-tujuan tersebut di atas menyebabkan dirinya sendiri bersama-sama hewan itu masuk ke dalam keadaan yang sangat membahagiakan."

Dua sloka di atas menjadi latar belakang dan acuan umat Hindu Bali dalam menggunakan hewan sebagai salah satu unsur dalam upakara Yadnya. Menjadikan hewan sebagai kurban suci diharapkan dapat membuat manusia lebih mampu mendekatkan diri dengan Tuhan dan akhirnya dapat menyatu dengan-Nya. Umat Hindu Bali pun percaya bahwa hewan yang dikurbankan tidaklah semata-mata "digunakan" sebagai keperluan manusia. Dengan pengorbanan, hewan yang dikurbankan sendiri akan mendapatkan tempat yang lebih baik setelah kematiannya. Kitab Manawa Dharmasastra V.40 menguraikan bahwa:

"Osadyah pasavo vriksastir, yancah paksinastatha, 
yajnyartham nidhanam praptah, prapnu vantyutsritih punah"

Arti dari sloka ini adalah, dikutip dari Pudja dan Sudantra (Pudja, I G., \& Sudantra, 1973), “Tumbuh-tumbuhan semak-semak, pohon-pohonan, ternak, seperti burung-burung lainnya yang telah digunakan sebagai sarana upakara akan lahir dalam tingkat yang lebih tinggi pada kelahiran yang akan datang."

Umat Hindu mempercayai punarbhawa, yaitu reinkarnasi atau kelahiran kembali. Maka, setelah makhluk hidup mati, ia akan terlahir kembali sesuai dengan karma wesana (bekas-bekas perbuatan)-nya. Punarbhawa akan terus berlanjut sesuai dengan perbuatan manusia, hingga ia akhirnya menyatu dengan Tuhan (moksa), yang merupakan tujuan utama dari umat Hindu. Jika manusia membawa karma (perbuatan) baik, maka ia dapat terlahir kembali sebagai manusia yang lebih baik daripada sebelumnya. Akan tetapi, jika ia banyak membawa karma yang tidak baik, besar kemungkinan ia akan terlahir kembali dengan keadaan yang lebih buruk, bahkan menjadi hewan dan tumbuhan.

Keistimewaan manusia, dalam kepercayaan Hindu, adalah ia mampu untuk membedakan baik dan buruk, sehingga ia bisa menentukan sendiri perbuatan seperti apa yang akan dia lakukan. Maka, kelahiran kembali adalah kesempatan bagi manusia untuk memperbaiki diri sehingga ia bisa membawa dirinya ke nirbanapadam (alam kelepasan), atau moksa. Dalam kitab Sarasamuscaya 4 disebutkan bahwa:

"Iyam hi yonih prathamā

Iyām prapya jagatipate

Atmanam sakyate tratum karmabhih

Subhalaksanaih"

Arti dari sloka ini adalah, dikutip dari Tim Penyusun (Tim Penyusun, 1996), "Menjelma menjadi manusia itu adalah sungguh- 
sungguh utama. Sebabnya demikian, karena ia dapat menolong dirinya dari samsara dengan jalan berbuat baik. Demikian keunggulan menjadi manusia.". Maka dari itu, dengan mengorbankan hewan, manusia telah membantu hewan tersebut untuk "naik tingkat" agar ia dapat menjelma sebagai manusia di kelahiran setelahnya. Dengan menjadi manusia, ia akan dapat memperbaiki diri dengan melakukan karma baik, sehingga jalan menuju moksa akan semakin dekat.

Kaitannya dengan penggunaan hewan upakara, khususnya oleh umat Hindu di Bali, pengelompokan didasarkan atas jumlah kaki dan habitat hidup dari hewan tersebut. Pengelompokan tersebut yaitu: Hewan suku pat (berkaki empat), soroh kedis (unggas), isin alas (hewan yang berhabitat di hutan), isin tukad (hewan yang berhabitat di sungai), isin carik (hewan yang berhabitat di sawah), isin pasih (hewan yang berhabitat di laut) dan gumatat-gumitit (hewan yang berukuran kecil, biasanya serangga atau ulat) (Budaarsa, K. \& Budiasa, 2013).

Hewan suku pat yang sering dipakai dalam upakara Yadnya adalah sapi, kambing, kerbau, lembu, babi, anak babi, anjing. Untuk soroh kedis, yang digunakan adalah angsa, ayam, bebek, merpati, gagak, kuntul, perkutut, tekukur. Lalu, isin alas yang biasa digunakan adalah cendrawasih, badak, babi hutan, kijang, rusa, trenggiling, landak, harimau, monyet, ular, kukang, ayam hutan, biawak, rubah kucing, musang, luwak, dan tikus. Untuk isin tukad, yang digunakan adalah udang, kepiting, nilam, sidat, lele, bulus, mujair, ikan gabus. Untuk isin carik, hewan yang biasa digunakan adalah belalang, capung, katak, belut, keong. Kerapu, teri, penyu tergolong ke dalam isin pasih. Terakhir, gumatat-gumitit yang biasa digunakan dalam upakara Yadnya adalah tawon, lebah, larva kumbang, kelabang, kalajengking, dan ulat bulu (Budaarsa, K. \& Budiasa, 2013).

Bagi umat Hindu Bali, penggunaan satwa dalam upacara Yadnya tidak dianggap sebagai penyembelihan biasa. Pasalnya, 
penyembelihan yang dilakukan untuk kepentingan upacara, umumnya didahului dengan berbagai tahapan penyucian dengan mantra tertentu sesuai dengan jenis satwa yang digunakan. Untuk satwa berkaki dua mantra yang digunakan adalah sebagai berikut:

"Om indah ta kita sang dwi pada, sakeng purwa desa sinangkan pamuliha, menembah ta kita kita maring sanghyang Iswara, Ong sang namah lingganta, wus samangkana pasangsarga kita ring sanghyang iswara, ayua ta kita tan mengantitiaken katuturan sanghyang Dharma, tutur-tutur ayua lali, inget-inget ayua lupa, nahan teka ring dalem kapatihan, yan kita dadi jatma dadi ya ika wiku sakti, saguna kayanta aturakena ring ulun, apan ulun umatukakna ri kita. Ong sang sadya ya namah."

Mantra tersebut menunjukkan bahwa hewan yang digunakan untuk upakara Yadnya, akan menjelma kembali menjadi makhluk yang lebih baik. Arti dari sloka ini adalah, dikutip dari (Budaarsa, 2017), “Om kau binatang yang berkaki dua, asalmu dari arah timur, di timurlah tempatmu, pulanglah ke arah timur bersujudlah kepada Sang Hyang Iswara, jangan sekali-sekali engkau melupakan ajaran Sang Hyang Dharma, semua wejangannya jangan kau lupakan, ingat-ingatlah selalu, jangan sampai lupa, apabila kau menjelma ke dunia, jadilah engkau wiku sakti, sesuai hasil kerjamu serahkanlah kembali kepada-Ku, Om semoga semuanya menjadi kenyataan atas anugerah-Nya." Sang Hyang Iswara dan Sang Hyang Dharma merupakan manifestasi dari Sang Hyang Widhi, Tuhan. Sang Hyang Iswara adalah penguasa penjuru Timur, dan Sang Hyang Dharma merupakan perwujudan Tuhan sebagai penjaga kebenaran dan keadilan di alam semesta.

Mantra yang biasanya digunakan dalam proses penyembelihan hewan pada umumnya adalah "Om pasu pasa ya widmahe sire ceda ya dimahe, tanno jiwah pracodayat." Mantra ini, jika diterjemahkan berarti "Om Hyang Widhi, hamba menyembelih hewan ini, semoga rohnya menjadi penyucian (Budaarsa, 2017)". 
Penyucian hewan ini disebut sebagai Mapepada yang merupakan bagian dari upacara Bhuta Yadnya. Mapepada berasal dari kata "pada" dalam bahasa Bali. Pada sendiri pada dasarnya memiliki dua makna, "sama" dan "kaki". Pada dapat diartikan sebagai penyamaan terhadap roh hewan yang akan digunakan untuk sarana upakara. Menurut budayawan I Gede Anom Ranuara, dengan diadakannya upacara Mapepada, diharapkan arwah dari hewan yang digunakan untuk upakara, ketika lahir kembali mengalami kenaikan tingkat atau tidak menjadi hewan kembali (Suyatra, 2018).

Mapepada dilaksanakan beberapa hari sebelum dilakukan pemotongan hewan untuk upacara. Biasanya, upacara ini menggunakan banten (sesajen) dengan tingkatan bebangkit dan dipuput (diselesaikan) oleh seorang sulinggih (pendeta Hindu). Upacara ini bertujuan untuk mendoakan dan memohon kepada Dewa Siwa agar hewan yang digunakan untuk upacara mengalami kenaikan derajat. Sulinggih (pendeta Hindu) pun merupakan simbol Siwa Sekala yang erat berkaitan dengan peleburan dosa (Suyatra, 2018).

Setelah semua upakara lengkap, upacara dilanjutkan dengan menuntun hewan yang akan dikurbankan mengitari tempat upacara sebanyak tiga kali. Konsep yang digunakan adalah Murwa Daksina yang artinya bergerak menuju ke atas atau menuju tingkat yang lebih tinggi. Setelah upacara Mapedada selesai sehingga semua hewan kurban telah disucikan, maka beberapa hari kemudian hewan tersebut akan dikurbankan dengan cara dipotong sebagai unsur dari upakara (Ranuara dalam Suyatra (Suyatra, 2018).

Dibandingkan dengan jenis Yadnya lainnya, hewan seringkali digunakan dalam Bhuta Yadnya. Bhuta Yadnya merupakan salah satu Yadnya yang merupakan jalan untuk menjaga keharmonisan alam atau bumi. Melalui pelaksanaan Bhuta Yadnya, semua unsur alam semesta akan terjaga 
keharmonisannya. Salah satu unsur penting dalam Bhuta Yadnya, khususnya upakara caru (upacara untuk mengharmoniskan hubungan antara manusia dan alam sekitarnya), adalah adanya unsur binatang atau hewan (wewalungan). Beberapa upacara Bhuta Yadnya yang dimaksud adalah Tawur Eka Dasa Rudra (upacara yang dilaksanakan untuk menyambut perhitungan perputaran tahun saka saat satuan dan puluhan mulai menjadi angka 1); Panca Wali Krama (upacara setiap tahun saka yang berakhiran dengan angka "0", panglong ping 15 (tilem) sasih kasanga, saat matahari terbit memasuki hari terakhir bulan kesembilan); dan segala jenis caru seperti Caru Manca Kelud, Caru Masesapuh Agung, Caru Balik Sumpah, dan lain sebagainya (Budaarsa, K. \& Budiasa, 2013).

\section{JALAN PANJANG MENUJU KESEJAHTERAAN HEWAN}

Sejak awal, manusia hidup berdampingan dengan makhluk-makhluk yang disebutnya sebagai hewan. Dalam perkembangan zaman, manusia memaknai hewan secara berbedabeda sehingga hubungan mereka dengan hewan pun juga memiliki perbedaan. Hal ini terjadi karena kondisi sosio-kultural yang juga berkembang. Misalnya, manusia pada zaman Yunani Kuno dan Romawi Kuno memakan hewan, memburunya, sekaligus juga mengaguminya (Hills, 2005). Pada masa ini, telah dilakukan pula usaha beternak sapi, babi, domba, dan kambing. Walaupun begitu, sebagian besar rakyat saat itu tidak sanggup untuk mengonsumsi daging sehingga mereka lebih banyak mengonsumsi sayur mayur. Maka dari itu, dapat dikatakan bahwa pada Masa Yunani Kuno dan Romawi Kuno, mengonsumsi daging hewan (seperti daging sapi) adalah sesuatu yang langka untuk dilakukan.

Pada masyarakat pra-industri, hewan dinilai oleh manusia sebatas dari kerja yang mereka hasilkan (Hills, 2005). Misalnya kerbau digunakan untuk menarik gerobak, anjing digunakan 
untuk menjaga para domba dan rumah-rumah. Saat itu, hewan dan manusia sudah mulai bekerja bersama di ladang.

Hewan pun digunakan untuk aspek lainnya yang berguna untuk manusia, yaitu hiburan (Hills, 2005). Di amfiteateramfiteater zaman Romawi, macan tutul, singa, harimau, beruang, dan gajah akan didorong untuk berperang, baik melawan satu sama lain ataupun melawan manusia (biasanya laki-laki), dari pemburu profesional hingga yang tidak bersenjata sekalipun. Pertunjukan ini dinikmati oleh penonton yang haus darah; mereka menghargai keterampilan para pemburu tetapi terkesan dengan pembantaian ratusan hewan di setiap pertunjukannya.

Selain itu, hewan juga digunakan sebagai kurban dalam berbagai ritual keagamaan (Hills, 2005). Dengan membunuh hewan dalam ritual keagamaan, seseorang dapat berterima kasih kepada para dewa, meminta bantuan kepada-Nya, atau mencari tahu apa yang mereka kehendaki. Mitos-mitos yang menceritakan kesenangan yang dinikmati oleh para dewa dalam pengorbanan manusia terjadi dalam budaya Yunani. Maka dari itu, hewan pun dikurbankan sebagai pengganti manusia. Entah hewan itu akan dibakar seluruhnya dengan anggur dan dupa, kadang-kadang dengan beberapa tetes darah manusia ditambahkan secara simbolis; atau bagian-bagian dari hewan akan dibakar dan sisanya dimakan. Semakin banyak jumlah hewan yang dikurbankan, maka semakin para dewa pun semakin senang sehingga pengorbanan seratus ekor lembu jantan bukanlah sesuatu yang dianggap luar biasa. Pembunuhan hewan sangat mendasar sehingga hampir tidak mungkin untuk menentangnya tanpa menentang agama tradisional sekaligus.

Dari beberapa contoh di atas, terlihat bahwa manusia sudah "menggunakan" hewan untuk membantu berbagai pekerjaan dan memenuhi kebutuhan hidup sejak sangat lama. Mengapa manusia memiliki kontrol yang sangat besar terhadap hewan? Pertanyaan ini bisa dijawab dengan pernyataan sederhana: bahwa manusia 
merasa superior daripada hewan. Padahal, sesungguhnya, apa itu hewan dan manusia? Menurut Bourke, konsep tentang manusia dan hewan sebenarnya sangat tidak stabil dan mudah untuk goyah. Konstruksi terkait "manusia" dan "hewan" itu memang selalu hadir setiap periode sejarah dan budaya, akan tetapi distingsinya "selalu dipertanyakan dan diperbarui" (Bourke, 2011).

Tradisi manusia, khususnya masyarakat Barat, mendefinisikan manusia sebagai zoon logon echon atau hewan rasional, hewan yang diberkahi dengan akal. Cara mendefinisikan hewan adalah dengan melihatnya sebagai sesuatu yang tidak memiliki apa pun yang dianggap "pantas" (proper) untuk manusia. Hal-hal tersebut misalnya ucapan, bahasa, akal, pengalaman kematian, daya berkabung, budaya, institusi, teknik, pakaian, dusta, kepura-puraan untuk berpura-pura, tawa, air mata, rasa hormat, dan lain-lain (Mallet dalam Derrida (Derrida, 2008). Dalam ketiadaan bahasa dan akal, hewan-hewan tetap terkunci dalam seperangkat rutinitas instingtif yang telah terprogram secara alami. Jadi, dengan begitu, hewan lebih bisa disebut sebagai mesin daripada manusia; sebagai objek daripada subjek (Wolfe, 2003).

Walaupun begitu, Charles Darwin berusaha menentang berbagai pemikiran dari para filsuf yang menunjukkan bahwa hewan adalah makhluk yang inferior dari manusia. Melalui teori evolusi-nya, Darwin menyatakan bahwa semua ragam spesies yang ada saat ini merupakan hasil evolusi dari para pendahulunya. Setiap spesies berkembang biak dan keturunannya akan meneruskan fitur-fitur dari orang tuanya dengan sedikit perubahan sesuai dengan kondisi eksternal. Hal inilah yang membuat seorang anak, semirip apapun dengan orang tuanya, tetap memiliki perbedaan. Hal ini pulalah yang menyebabkan banyak spesies berkembang melalui apa yang disebut sebagai seleksi alam (Hills, 2005). 
Teori evousi tidak memungkiri adanya kemungkinan bahwa manusia memiliki alasan dalam mendominasi hewan. Akan tetapi, adanya teori ini menyadarkan bahwa manusia sesungguhnya tidaklah superior dari apa yang manusia sebut sebagai hewan karena ia sendiri merupakan turunan dari hewan.

Kesadaran bahwa hewan dan manusia pada dasarnya berasal dari pendahulu yang sama, membuat banyak orang mencoba untuk mengatur relasi hewan dan manusia secara lebih baik. Hills (2005) menjelaskan hal ini secara runtut. Sebelum tahun 1822 di Inggris, hukum memandang hewan hanya sebagai properti; sebagai benda yang harus dilindungi bukan demi mereka sendiri, tetapi demi pemiliknya. Hukum ini melindungi hewan agar tidak dicuri atau diserang oleh orang yang bukan pemilik mereka, dan juga menghukum perburuan rusa, ikan, dan hewan ternak. Akan tetapi, saat itu tidak ada hukum yang mengatur tentang perlakuan pemilik terhadap hewan yang dimilikinya. Akibatnya, seseorang dapat melakukan apapun terhadap hewan yang dimilikinya.

Ketika hewan dipandang hanya sebagai properti, anggapan hukum adalah bahwa apapun yang seseorang lakukan terhadap hewan yang dimilikinya (atau yang tidak dimiliki oleh siapapun) dapat diterima kecuali ada undang-undang khusus yang menentangnya. Anggapan yang timbul setelahnya adalah bahwa manusia memiliki hak untuk melakukan apapun terhadap hewanhewan tersebut. Para juru kampanye kesejahteraan hewan awal merasa sangat sulit untuk mengubah undang-undang tentang hewan ini. Mereka khawatir bahwa jika hukum ini diubah, misalnya untuk melarang praktik-praktik tertentu terhadap hewan, hal ini justru membatasi hak asasi manusia terutama hak atas properti mereka sendiri.

Pada awal tahun 1800, beragam upaya dilakukan di Inggris untuk melarang hiburan populer yang menggunakan hewan, seperti bear-baiting (mengumpan beruang) yang mengikat seekor 
beruang di sebuah tiang dan mendorong anjing-anjing ganas untuk menyerangnya. Upaya-upaya larangan ini gagal, tetapi pada tahun 1822, undang-undang kesejahteraan hewan yang pertama di Inggris disahkan: menjadi pelanggaran bagi siapapun untuk memperlakukan secara kejam' setiap ternak, domba atau kuda, dengan sanksi berupa denda. Pada tahun 1835, undangundang itu diperluas untuk mencakup anjing dan hewan peliharaan lainnya (dan hukuman penjara diperkenalkan sebagai hukuman yang mungkin); perkelahian hewan dan pengumpan juga dilarang. Pada waktu yang hampir bersamaan, beberapa negara lain juga meloloskan undang-undang terkait kekejaman terhadap hewan. Sebagai contoh, di Amerika Serikat, undangundang disahkan untuk melarang penderitaan pada hewan; tetapi mereka tidak memiliki banyak pengaruh, karena hampir semua penggunaan hewan oleh manusia dianggap sah, tidak peduli bagaimana hewan menderita, atas dasar bahwa manusia memiliki kekuasaan atas dunia hewan.

Sejak 1835, hukum Inggris biasanya mengatur aktivitas daripada melarang secara langsung. Sebagai contoh, pada tahun 1876, Undang-Undang tentang Kekejaman terhadap Hewan diloloskan untuk mengatur eksperimen pada hewan: menjadi suatu pelanggaran untuk melakukan eksperimen yang memberikan rasa sakit pada hewan hidup, kecuali percobaan itu akan meningkatkan pengetahuan fisiologis, mengurangi penderitaan atau memperpanjang umur. Saat ini di Inggris, para ilmuwan harus memiliki lisensi untuk bereksperimen pada hewan, dan proyek mereka juga harus memiliki lisensi. Percobaan hewan diizinkan hanya jika mereka diharapkan memberi kita manfaat yang signifikan dan tidak ada alternatif yang memadai. Namun demikian, tidak ada konsensus internasional tentang hukum yang mengatur eksperimen hewan. Undang-undang di Inggris saat ini termasuk yang paling menuntut di dunia.

Gerakan terkait animal welfare (kesejahteraan hewan) modern dibangkitkan oleh Animal Liberation karya Peter Singer. 
Buku ini membuat pembacanya mempertanyakan perlakuan manusia terhadap hewan. Buku ini kemudian mengubah perspektif banyak orang terkait hewan dan bahkan membuat mereka beralih ke vegetarianisme. Peter Singer sendiri merupakan seorang utilitarian yang percaya bahwa mengusahakan kebahagiaan sebanyak mungkin dan kesakitan sesedikit mungkin adalah kewajiban moral manusia. Maka dari itu, menurutnya, semua makhluk yang memiliki kemampuan untuk merasa (sentient) memiliki status moral yang setara, dimana kesakitan dan kesenangan mereka harus dihitung secara setara pula; tidak ada yang lebih diuntungkan dari yang lain

Bagi Singer (Singer, 2002), manusia semestinya memberlakukan prinsip dasar kesetaraan ke kelompok hewan. Perpanjangan prinsip dasar kesetaraan dari satu kelompok ke kelompok lain, menurut Singer, bukanlah berarti bahwa kita harus memperlakukan keduanya dengan cara yang persis sama, atau memberikan hak-hak yang sama persis ke kedua kelompok tersebut. Prinsip dasar kesetaraan tidak membutuhkan perlakuan yang sama atau identik; ia membutuhkan pertimbangan yang setara. Pertimbangan setara untuk berbagai makhluk inilah yang dapat mengarah ke perlakuan yang berbeda dan hak yang berbeda pula. Klaim kesetaraan tidak bergantung pada intelegensi, kapasitas moral, kekuatan fisik, atau fakta sejenis. Kesetaraan adalah sebuah ide moral, bukan sebuah tuntutan atas fakta. Maka dari itu, menurut Singer, kita tidak perlu menuntut apapun ke suatu makhluk untuk menjadikannya setara dengan kita.

Faktor penting mengapa sebagian besar manusia sangat sulit untuk mengakui kesetaraan hewan terhadapnya adalah karena spesiesisme. Spesiesisme adalah prasangka atau perbuatan dengan bias yang berpihak pada kepentingan anggota spesies sendiri dan bukan terhadap anggota spesies lain. Maka dari itu, sebagian besar manusia di Bumi, menurut Singer, adalah spesiesis karena mereka seringkali menggunakan klaim "manusia lebih 
tinggi derajatnya daripada hewan" demi memenuhi kepentingan mereka sendiri.

Kini, pertanyaannya bukan apakah hewan bisa berpikir atau apakah hewan bisa berbicara, tapi apakah hewan bisa menderita? Menurut Singer (Singer, 2002), kapasitas untuk menderita dan merasa senang adalah prasyarat dari suatu makhluk memiliki kepentingan; sebuah kondisi yang harus terpenuhi sebelum kita bisa berbicara tentang apa itu kepentingan. Kapasitas untuk menderita dan merasa senang tidak hanya perlu, tapi juga mumpuni bagi kita untuk mengatakan bahwa suatu makhluk memiliki kepentingan, setidaknya kepentingan untuk tidak menderita (paling minimal). Maka dari itu, jka suatu makhluk menderita, tidak ada justifikasi moral apapun untuk menolak memasukkan penderitaan itu ke dalam pertimbangan kita. Oleh karenanya, semua makhluk hidup (mereka yang dapat merasakan rasa sakit dan kesenangan) memiliki status moral.

Memiliki status moral tidak sama dengan memiliki hak. Beberapa hak manusia bergantung pada kemampuan manusia untuk berpikir dan bernalar. Akan tetapi, para aktivis kesejahteraan hewan menyatakan bahwa hewan memiliki hak paling mendasar, yakni hak untuk hidup. Mereka mengatakan bahwa hewan memiliki hak untuk tidak dibunuh demi makanan, untuk hiburan, atau untuk penelitian ilmiah, sama seperti manusia.

Maka dari itu, dari kacamata animal welfare, pembunuhan hewan untuk kepentingan apapun adalah sesuatu yang salah. Ketika seekor hewan dibunuh, maka haknya yang paling mendasar, yakni hak untuk hidup, tidak terpenuhi. Bahkan, hak itu tidak sempat "dituntut" oleh hewan tersebut karena mereka tidak memiliki kapasitas itu. Kita sebagai manusia yang memahami hal itu sepantasnya bisa mencegah hal tersebut terjadi. Maka dari itu, penggunaan hewan sebagai kurban dalam ritual 
keagamaan, juga dianggap sebagai sesuatu yang menyalahi hak hewan.

\section{MENGHORMATI DAN MEMULIAKAN HEWAN}

Menurut Wolfe (Wolfe, 2003) dalam Asmarani (Asmarani, 2018) banyak teoretikus dalam tiga dekade terakhir yang memberikan perhatian besar terhadap persoalan hewan. Hal ini, menurutnya, disebabkan oleh dua faktor besar. Faktor pertama adalah karena adanya interogasi terhadap figur manusia dalam membentuk sejarah dan masyarakat melalui teori kritis. Faktor kedua adalah perubahan radikal dari posisi hewan dalam ilmuilmu di luar Ilmu Kemanusiaan. Ilmu Kemanusiaan sedang berusaha untuk menyesuaikan diri dengan evaluasi dari status "nonhuman-animals" dalam masyarakat. Ilmu-ilmu baru seperti etologi kognitif dan ekologi telah mengajukan pertanyaan mengenai validitas kategori-kategori yang digunakan untuk mempertahankan antroposentrisme (seperti bahasa, teknologi, dan kebudayaan) yang memisahkan manusia dan hewan. Kini mulai terlihat bahwa batas yang membedakan karakteristik biologis manusia dan hewan begitu tipis (Wolfe, 2003).

Diskursus mengenai animal welfare terlihat bahwa pergeseran budaya akan selalu terjadi seiring berjalannya waktu. Kita bisa melihat bahwa terdapat pergeseran pola pikir yang awalnya hanya memandang hewan sebagai sesuatu yang "digunakan" oleh manusia, menjadi memiliki kedudukan yang setara dengan manusia. Para filsuf yang sebelumnya tidak terlalu mempermasalahkan relasi hewan dan manusia, terlebih lagi penggunaan hewan oleh manusia dalam berbagai bidang, perlahan-lahan mulai menyadari bahwa ada sesuatu yang dapat dipelajari dan diperbaiki dari relasi ini. Dua filsuf yang dikutip dalam artikel ini, Derrida dan Wolfe, adalah filsuf yang memiliki perhatian khusus terhadap relasi hewan dan manusia. 
Sejauh diskusi yang dijabarkan di atas, jika dipandang dari kaca mata animal welfare, penggunaan hewan dalam upacara Yadnya yang dilakukan oleh umat Hindu Bali tentu merupakan sesuatu yang salah karena hewan digunakan semata-mata untuk kepentingan manusia dan haknya untuk hidup pun terabaikan. Hal ini juga didukung dengan pandangan umum yang mengoperasikan premis bahwa hewan memiliki derajat yang lebih rendah dari manusia dalam sebuah hierarki kosmik. Maka dari itu, manusia dianggap memiliki hak untuk menggunakan hewan untuk berbagai kepentingannya. Gagasan ini ditemukan di sebagian besar agama dan kepercayaan di dunia dan termaktub dalam ritual dan praktik keagamaan manusia sehari-hari (Donaldson, S. \& Kymlicka, 2011).

Akan tetapi, umat Hindu telah memiliki landasan untuk menjalankan segala praktik keagamaannya, termasuk penggunaan hewan untuk upakara. Hal tersebut sudah dibahas di dua sub sebelumnya. Maka dari itu, klaim bahwa pengorbanan ini harus dihentikan kini menjadi bermasalah. Suatu budaya tidak serta merta lahir begitu saja; ia memerlukan suatu proses agar dapat diterima dan berkelanjutan. Umat Hindu Bali telah memiliki rasionalisasinya sendiri tentang mengapa mereka menggunakan hewan dalam upacara Yadnya karena selain itu merupakan kelengkapan yang harus ada, budaya pengorbanan hewan juga dilakukan dengan berlandaskan kepercayaan bahwa setelah dikurbankan, hewan tersebut dapat diberikan "jalan yang lebih mudah dan lebih baik" untuk dapat kembali kepada Tuhan. Maka dari itu, bisa dikatakan bahwa penggunaan hewan sebagai kurban justru memuliakan hewan itu sendiri.

Govindrajan (Govindrajan, 2018) mengatakan bahwa memelihara dan membesarkan hewan untuk akhirnya menjadi persembahan dalam upacara Yadnya, adalah suatu pekerjaan yang berharga. Menawarkan hewan tersebut untuk para dewata dalam bentuk pengorbanan memiliki efek ganda. Pertama, hal ini akan memperdalam hubungan antara mereka yang mempersembahkan 
kurban dengan makhluk yang dikurbankan, dan; kedua, hal ini akan menunjukkan bakti yang mendalam kepada Tuhan karena telah menyerahkan sesuatu yang berharga. Dengan demikian, hal ini memperkuat intensitas ikatan devosional antara pemuja dan yang dipuja.

Argumen ini memperlihatkan bahwa sesungguhnya berbagai klaim dari aktivis animal welfare tidak dapat diterapkan secara universal ke semua praktik yang menghubungkan manusia dan hewan. Semua klaim untuk universalitas ini akhirnya menyentuh isu-isu pluralisme budaya. Mengingat berbagai budaya dan agama di dunia memiliki pandangan yang sangat berbeda tentang status moral hewan, bagaimana bisa satu pandangan mengklaim berlaku universal? Menurut Donaldson \& Kymlicka (Donaldson, S. \& Kymlicka, 2011), bukankah ini bentuk dari eurosentrisme dan imperialisme moral untuk memaksakan pandangan "masyarakat Barat" tentang hak-hak hewan pada masyarakat lain? Keberatan ini sangat menonjol dan kontroversial dalam kaitannya dengan masyarakat adat, beberapa di antaranya terlibat dalam bentuk perburuan dan perangkap yang telah dilarang oleh aktivis hak-hak hewan (misalnya, perburuan paus, perburuan anjing laut). Dilihat dari sejarah panjang imperialisme Barat terhadap masyarakat adat, sulit untuk tidak melihat ini sebagai contoh lain di mana masyarakat Barat mengklaim hak untuk menjalankan kekuasaan atas masyarakat pribumi dengan alasan bahwa yang masyarakat tersebut adalah terbelakang, primitif, atau bahkan biadab.

Dalam setiap budaya dan agama, ada keragaman sumber moral (atau keragaman interpretasi dari sumber-sumber moral) yang mana beberapa di antaranya cocok dengan ide-ide kesejahteraan hewan, yang lain tidak. Menurut Taylor (1999) dalam Donaldson \& Kymlicka (Donaldson, S. \& Kymlicka, 2011), hak asasi manusia mencapai universalitas tidak melalui serangkaian cangkokan asing ke dalam masyarakat yang tidak memiliki "DNA" budaya yang sesuai, tetapi melalui proses-proses 
yang mencerminkan sumber-sumber moral yang beragam, yang mengarah idealnya ke "konsensus tanpa paksaan" pada serangkaian nilai-nilai atau prinsip-prinsip bersama. Begitu pun agenda terkait animal welfare untuk menjamin animal rights harus dilakukan tanpa adanya paksaan terhadap sesama masyarakat yang juga bertujuan untuk bersama-sama memuliakan hewan.

\section{SIMPULAN}

Dalam praktiknya, umat Hindu menggunakan hewan sebagai bagian dari upakara. Penggunaan hewan sudah disebutkan dalam berbagai kitab yang menjadi acuan umat Hindu dalam melaksanakan agamanya. Diketahui dari kitab Manawa Dharmasastra V.42, dicantumkan bahwa Tuhan menciptakan binatang dan tumbuhan untuk tujuan upacara-upacara kurban, dengan maksud untuk kebaikan bumi. Selain itu, umat Hindu Bali pun percaya bahwa hewan yang dikurbankan akan mendapatkan tempat yang lebih baik setelah kematiannya.

Jika dipandang dari kacamata animal welfare, penggunaan hewan dalam upacara Yadnya yang dilakukan oleh umat Hindu Bali tentu merupakan sesuatu yang salah karena hewan digunakan semata-mata untuk kepentingan manusia dan haknya untuk hidup pun terabaikan. Hal ini juga didukung dengan pandangan umum yang mengoperasikan premis bahwa hewan memiliki derajat yang lebih rendah dari manusia dalam sebuah hierarki kosmik. Maka dari itu, manusia dianggap memiliki hak untuk menggunakan hewan untuk berbagai kepentingannya.

Akan tetapi, umat Hindu telah memiliki landasan untuk menjalankan segala praktik keagamaannya, termasuk penggunaan hewan untuk Yadnya. Bahkan, bisa dikatakan bahwa penggunaan hewan sebagai kurban justru memuliakan hewan itu sendiri. Maka dari itu, klaim bahwa pengorbanan ini adalah sesuatu yang salah, justru menjadi bermasalah. Argumen ini memperlihatkan bahwa 
sesungguhnya berbagai klaim dari aktivis animal welfare tidak dapat diterapkan secara universal ke semua praktik yang menghubungkan manusia dan hewan. Mengingat berbagai budaya dan agama di dunia memiliki pandangan yang sangat berbeda tentang status moral hewan, bagaimana bisa satu pandangan mengklaim berlaku universal?

\section{DAFTAR PUSTAKA}

Asmarani, N. N. O. (2018). Hidup di antara batas: Relasi hewan dan manusia. BALAIRUNG: Jurnal Multidisipliner Mahasiswa Indonesia, 1(2), 167-175.

Bourke, J. (2011). What it means to be human: Reflections from 1791 to the present. Counterpoint Press.

Budaarsa, K. \& Budiasa, K. M. (2013). Jenis Hewan Upakara dan Upaya

Pelestariannya. https://repositori.unud.ac.id/protected/storage/upload/repos\% 09itori/ID3_19581204198503100211081408838makalahjenis\%09hewan-upakara-pdf.pdf.

Budaarsa, K. (2017). Penggunaan Satwa dalam Upacara Agama Hindu. Suara Pakar Universitas Udayana. https://www.unud.ac.id/in/suarapakar19-Penggunaan\%09Satwa-dalam-Upacara-Agama-Hindu.html

Derrida, J. (2008). The Animal that Therefore I Am. Fordham University Press.

Donaldson, S. \& Kymlicka, W. (2011). Zoopolis: A Political Theory of Animal Rights. Oxford University Press.

Govindrajan, R. (2018). Animal Intimacies: Interspecies Relatedness in India's Central Himalayas. The University of Chicago Press.

Hills, A. (2005). Do Animals Have Rights? Icon Books.

Kleden, I. (1987). Sikap ilmiah dan kritik kebudayaan. Lembaga 
Penelitian, Pendidikan dan Penerangan Ekonomi dan Sosial. https://books.google.co.id/books?id=_cXZAAAAMAAJ

Pidarta, M. (2016). Esensi Agama Hindu (Edisi VI). Unesa University Press.

Pudja, I G., \& Sudantra, T. R. (1973). Manawa Dharmasastra. Lembaga Penerjemah Kitab Suci Weda.

Singer, P. (2002). Animal liberation. Ecco.

Suyatra, I. P. (2018). Begini Makna dan Tujuan Mapedada dalam Upacara Hindu di Bali. https://baliexpress.jawapos.com/read/2018/01/14/40258/begi\%0 9ni-makna-dan-tujuan-mapepada-dalam-upacara-hindu-di\%09bali.

Tim Penyusun. (1996). Buku Pendidikan Agama Hindu untuk Perguruan Tinggi. Penerbit Hanuman Sakti.

Wolfe, C. (2003). Animal Rites: American Culture, the Discourse of Species, and Posthumanist Theory. The University of Chicago Press. 